\title{
Island Africa and Vertebrate Evolution: A Review of Data and Working
}

\section{Hypotheses}

Jean-Claude RAGE* ${ }^{\mp}$ and Emmanuel GHEERBRANT

${ }^{\mp}$ Deceased after submission on March 30, 2018

CR2P - Centre de Recherches en Paléontologie (Paris), UMR CNRS 7207, Sorbonne Université, MNHN/CNRS/UPMC, 57 rue Cuvier, CP 38, 75005 Paris, France

*corresponding author: emmanuel.gheerbrant@mnhn.fr

Abstract From mid-Cretaceous to Early Miocene, Africa was geographically isolated as a gigantic island, the Island Africa. This considerably impacted local evolution of continental vertebrates. The native fauna of the Island Africa is and was depauperate for poorly known reasons. Although an Island, Africa was intermittently connected to Laurasia by discontinuous routes across the Neo-Tethys. Owing to these routes, various allochthonous groups of Eurasian origin entered Africa where they found favorable evolutionary conditions with relaxed competitive pressure; many of these groups evolved successfully, giving rise to new African clades and important endemic radiations. Thus, Island Africa acted as a secondary cradle, boosting the evolution of stem groups of Eurasian origin. Notably, all Cenozoic African mammals likely derived from stem groups of Laurasian origin. A remarkable number of endemic African lineages evolved successfully in extant African faunas, and even colonized several continents. They survived in particular the Miocene event of the Great Old 
World Interchange. The earlier faunal relations of Africa and Eurasia across the Tethys likely contributed to the success of the endemic African evolution.

Keywords African endemism. Cretaceous. Dispersals. Eurasia. Vertebrata. Mammalia. Paleogene. Secondary cradle.

Running head Vertebrate evolution in Island Africa

\section{Introduction}

This work aims to review, based on our current knowledge, some broad questions on the vertebrate evolution in the Arabo-African Island, that could be only briefly mentioned or addressed in our paper Gheerbrant et Rage (2006). The geographical history of Africa is marked by two major events: separation of the Arabo-African plate from other continents during the Mesozoic and connection to Eurasia during the Cenozoic. As a result of these two events, the African continental faunas have evolved in four successive major paleobiogeographical contexts since the Jurassic: 1) Pangean Africa; 2) Gondwanan Africa; 3) insular Arabo-Africa; and 4) Africa in the Old World. We focus here on a critical but still poorly known stage of the African history: the evolution of the Arabo-Africa island hereafter referred to as Island Africa - which overlapped parts of the Mesozoic and Cenozoic, during ca. $80 \mathrm{Ma}$ (Fig. 1). The faunal evolution of the Island Africa includes three critical periods in the emergence of modern faunas, which are well documented in Laurasia: The Cretaceous-Paleogene (K-Pg), Paleocene-Eocene and Eocene-Oligocene transitions. These global events more or less affected the endemic African faunas, but their biotic local impact 
remains much more poorly known than in most other continental provinces. The insular context strongly impacted evolution of the African continental biotas. However, while the process of separation from other continents and contact with Laurasia are relatively well known, the evolutionary history of biotas in the Island Africa remains largely unknown. The question of the evolutionary role of the Island Africa was raised in recent phylogenetic analyses and/or paleontological studies (e.g., Gorscak and O'Connor 2016; Jacobs et al. 2016; Eberle et al. 2017; Elewa 2017).

The main barrier encountered in studying the time interval that corresponds to the existence of Island Africa is the rarity of fossils as compared to other continental provinces, including Gondwanan ones such as South America. This rarity - sometimes called "African Gap" (O'Connor et al. 2006; Gottfried et al. 2009) - was often regarded as a consequence of the lack of field work in Africa, absences being only non-significant "pseudo-absences" (sensu Upchurch et al. 2002). However, field studies - which started early during the first naturalist and mining explorations of the continent - have not been infrequent, far from it, and it now appears that rarity of fossils is implicitly accepted as the natural condition, not an artifact; this is for instance implied by all studies that evidenced relationships between South America and Madagascar-India, and Australia - but not with Africa (see below).

\section{PLACE FIGURE 1 ABOUT HERE; WIDTH = 2 COLUMNS (FULL PAGE WIDTH)}

Our objective is not to trace the history of Africa during this period, which is an impossible task for the time being, but to make a review of the best of our knowledge, to emphasize the main problems that face us, and to propose hypotheses where possible.

The problems we would like to stress are as follows: 
What was the native fauna of Africa, that is to say the autochthonous continental fauna that inhabited Africa at the beginning of isolation? What was its evolutionary fate?

How and why was Africa depauperate during isolation? What event(s), if any, could have caused low African paleobiodiversity?

Why were allochthonous forms, i.e. immigrants that entered Island Africa, so successful?

Why did a number of African taxa successfully survived Eurasian immigrants when Africa contacted Eurasia, and even colonized other continents?

We here review and discuss the available data on these questions, following our former discussion in Gheerbrant et Rage (2006).

\section{The native African fauna (Fig. 2)}

The African native fauna is naturally defined as the assemblage of autochthonous taxa present in Africa just after separation from South America. They are vicariant taxa resulting from the splitting of Gondwana (Fig. 2). They were present on West Gondwana, i.e. the Africa-South America block that was more precisely named Samafrica by Upchurch (2008), which may be regarded as the starting point in the paleobiogeographical history of the Island Africa. The native taxa of the Island Africa are Samafrican (= West Gondwanan) vicariants, it being understood that the Samafrican stock likely included older, pan-Gondwanan and even Pangean taxa (e.g., some fishes and mammals). 


\section{PLACE FIGURE 2 ABOUT HERE; WIDTH = 1.5 COLUMN}

Among the vicariants may be cited various clades that are still living in Africa:

freshwater osteichthyans (Lepidosirenidae), amphibians (Pipidae, Atlanticanura sensu Frazão et al. 2015), acrodontan lizards, and pelomedusid chelonians. Several extinct groups found in the Cretaceous of Africa are also evidence of this vicariance event: freshwater fishes (Mawsonia; Carvalho and Maysey 2008), some extinct chelonians (Araripemydidae, Euraxemydidae; Gaffney et al. 2006; Sereno and ElShafie 2013), crocodilians (Araripesuchus; clades of Pholidosauridae, including the genus Sarcosuchus; Turner 2006; Le Loeuff et al. 2010), dinosaurs (Abelisauridae, Carcharodontosauridae, Rebbachisauridae (Sereno et al. 2004; Novas et al. 2005) and mammals (Haramyida, Eutriconodonta, Dryolestoidea, stem Cladotheria, and probably Gondwanatheria) (see also Gheerbrant and Rage 2006: Tab. 1). However, it should be noted that the extension of some of these taxa into the Late Cretaceous of Africa remains unknown; this is especially true for the mammals that are poorly documented in the Late Cretaceous of Africa (Table 1). Although this list of taxa needs to be confirmed for some of them, and is obviously not exhaustive and may be increased, it nevertheless shows that no native African mammal groups survived up to the present and that the above mentioned extinct groups did not survive the Cretaceous in Africa. The only possible exception is raised by the tribosphenidan mammals from the early Cretaceous Anoual-Ksar Metlili locality (Sigogneau-Russell 1991, Kielan-Jaworowska et al. 1992) which could be the stem group of in particular the early Cenozoic African therians. This is the hypothesis of an African Cretaceous origin of the placentals as suggested by KielanJaworowska (1992) and of the afrotherians as suggested by molecular studies (e.g., Dos Reis et al. 2012). However, it should be noted that early tribosphenidans are unknown in other 
Gondwanan continents, and that the Anoual-Ksar Metlili tribosphenidans are presumed to be not African natives (Luo et al. 2001). Their presence in Africa might indicate a Jurassic/Cretaceous trans-Tethyan dispersal from Eurasia. Mesozoic early tribosphenic mammals are known in South America, Madagascar, India (Parmar et al. 2015) and Australia, but they belong to the convergent Gondwanan clade Australosphenida (Luo et al. 2001). Most remarkably, the Gondwanan clade Australosphenida remains unknown in Africa.

It is generally acknowledged that the separation between Africa and South America took place by the Aptian-Albian transition (Gheerbrant and Rage 2006), that is about 110 Ma. Recently, Granot and Dyment (2015) suggested a younger age, ca. 100 Ma on geophysical bases. However, the separation of the two continents likely occurred earlier, between 110 and $100 \mathrm{Ma}$, and possibly close to $103 \mathrm{Ma}$ (Heine et al. 2012, Seton et al. 2012). Anyway, the breakup did not separate abruptly and synchroneously everywhere the two areas; for an indeterminate period of time, the separation zone likely acted as a filter route, as suggested by the peculiar environment (presence of amounts of evaporites; Burke and Sengör 1988; Chaboureau et al. 2012). Gorscak and O'Connor (2016), and Gorsack et al. (2017) also showed that the diachronic opening of the South Atlantic from the South to the North (i.e., northward rifting) led to a South-North faunal provinciality of the Cretaceous African faunas. Possible intermittent links between South America and Africa by island chains extending across an already opened South Atlantic were discussed by various authors (see Ezcurra and Agnolin 2012, Oliveira et al. 2009).

\section{The fauna of the Island Africa}


After separation from South America, began a period of African isolation that lasted about 80 million years. The Arabo-African plate was a gigantic island, i.e., the Island Africa, geographically set apart from other continents (Fig. 1). Its fossil record confirms strong biotic endemicity, but it also shows that it was not fully isolated biologically.

The fate of the native fauna (Fig. 2)

Most of the native taxa did not clearly expand in Africa or even became extinct, leaving a poor fauna with low diversity and low competition pressure in the Island Africa. Among the above-mentioned clades, the Atlanticanura and Acrodonta widely diversified. However, the African component of the Atlanticanura has remained less diversified than representatives in other continents. Acrodontan lizards (today "agamids" plus chamaeleonids) have had a somewhat peculiar history. They were present in Samafrica by the mid-Cretaceous (Apesteguía et al. 2016) but they did not survive at most the Campanian in South America (Simões et al. 2015) whereas they largely diversified in Africa.

Mammals illustrate the unsuccessful evolution of the native fauna. The Mesozoic mammals known in Africa, most from the early Cretaceous of the Anoual-Ksar Metlili locality (Morocco), are represented by rare haramyidans (incl. family Hahnodontidae: Huttenlocker et al. 2018), a possible gondwanatherian, eutriconodonts, some "symmetrodontans" (stem Trechnotheria), stem cladotheres (non-tribosphenic therians) such as dryolestids and peramurans, and stem tribosphenic therians (Tribosphenida). They are predominated by African natives. All taxa identified as the African mammal natives did not survive the K-Pg boundary, even if we do not know if they went extinct at this time or before. This is a noticeable difference with South America were at least two archaic Mesozoic taxa (South 
American natives) survived to the K-Pg boundary in the Paleocene: the peligrotheriid dryolestoids and the sudamericid gondwanatheres. The paleobiogeographical origin of the African Mesozoic native mammals remains poorly understood. Some are possible Gondwanan vicariants (Gondwanatheria, ?Dryolestoidea (see Chornogubsky 2011)). Others may be early Pangean vicariants (Haramyida, most Eutriconodonta, "symmetrodontans", ?Dryolestoidea, ?Peramura).

The Mesozoic African mammal taxa which might possibly belong to lineages crossing the K-Pg boundary are represented by the tribosphenic therians (tribosphenidans) Tribotherium and Hypomylos from the Anoual-Ksar Metlili locality (Morocco). They could belong to the stem groups of the Cenozoic eutherian and placentals (Kielan-Jaworowska 1992; Luo et al. 2001; Kielan-Jaworowska et al. 2004), and in particular of the afrotherians known in Africa. However, tribosphenidans are most likely of Laurasian origin (Luo et al. 2001; Kielan-Jaworowska et al. 2004), and are instead not native mammals in Africa. Alternatively, Sigogneau-Russell (1991) and Sigogneau-Russell et al. (2001) postulated the controversial view that the early African tribosphenic mammals such as Tribotherium found in Anoual-Ksar Metlili locality may indicate a "Gondwanan" origin of the Tribosphenida (incl. Theria).

The poor evolutionary success of most of the native African clades, and even the extinctions of several native groups rendered the African native assemblages markedly depauperate in the Late Cretaceous and Paleogene. The causes of such a depauperate Island Africa remain poorly understood. 


\section{The Island Africa: an underpopulated biotic province?}

During isolation, the fauna of Africa was poor and, more specifically, noticeable absences are observed. Several taxa, well represented elsewhere in Gondwanan continents, are lacking in Africa (Gheerbrant and Rage 2006), among them: dipnoans of the Ptychoceratodus madagascariensis group and Atlantoceratodus (Cione et al. 2007), carnotaurine (sensu Sereno et al. 2004) dinosaurs, chelid turtles, non-acrodontan iguanians, boine snakes, australosphenidan and probably gondwanatherian mammals. The absence of the Gondwanan clade australosphenidans is peculiarly remarkable. Aside from animals, the tree Nothofagus is a good example of a widely distributed Gondwanan taxon lacking in Africa. Compared to the noticeable cosmopolitanism of faunas of other Gondwanan continents, the Island Africa appears peculiar, i.e. endemic, and depauperate.

An attempt at a quantitative comparison between African faunas and those from other continents provided contrasting results. It faced various problems: taxonomic conceptions different from author to author, presence of several taxa incertae sedis and stem groups not included in families, and uncertain stratigraphic positions of localities. However, the estimated numbers of species show that the African fauna was less diverse and less rich than that of South America, which is the last Gondwanan continent which was joined to Africa. The relative paucity of African faunas with regard to those of other continents, which is quite well illustrated by the continental distribution and relative number of known Cretaceous and Paleogene vertebrate localities (Fig. 3), was already noted in several studies, e.g. Gheerbrant and Rage (2006), Krause et al. (2006), Gorscak et al. (2017). 
O'Connor et al. (2006) referred to this African pattern as the "African Gap", a notion taken up by Gorscak et al. (2017).

PLACE FIGURE 3 ABOUT HERE; WIDTH = 2 COLUMNS (FULL PAGE WIDTH)

Part of the absences of Gondwanan taxa in Africa might result from selective extinctions (Figs. 2, 4, 5) which impoverished the African fauna more markedly than in the other continents; in addition, paucity was likely increased by the fact that various Gondwanan groups did not enter the Island Africa. A striking illustration of this African pattern is provided by clades that are present in South America, Madagascar and India but that are lacking in intervening Africa (i.e. most of the above cited groups; Krause et al. 1997; Rage 2003; Krause et al. 2006). Similarly, Woodburne and Case (1996), Goin et al. (2016) and Poropat et al. (2016) disclosed faunal affinities between South America and Australia, including Antarctica, but excluding Africa. These paleobiogeographical relationships correspond to the "Africa first" model of Sereno et al. (2004) (see also Krause et al. 2006).

Mammals from the Late Cretaceous offer one example of this African characteristic. Whereas only one undetermined species of mammal (known by one vertebra from the Cenomanian of Libya; Nessov et al. 1998; Rage and Cappetta 2002) is recorded for the whole Late Cretaceous period in Africa, a noticeable diversity of 24 species of Late Cretaceous mammals are found in South America (Rougier et al. 2011), mostly of archaic groups (Gondwanatheria and Dryolestoidea, especially the endemic radiation of Meriodiolestida that includes 16 described species). Even Madagascar has yielded a small diversity of Late Cretaceous endemic mammals in the locality of Berivotra, including one or two species of 
multituberculates, two gondwanatherians, and one zhelestid eutherian (Averianov et al. 2003; a species initially interpreted as a marsupial by Krause 2001). The Late Cretaceous fauna of India also yielded five eutherians (adapisoriculids, and one "condylarth"), one gondwanatherian, and one haramyidan (Prasad 2012). As far as large "reptiles" are concerned, the diversity in Africa is not markedly lower than that in South America during the early Late Cretaceous, but it markedly fell during the latest Cretaceous. According to Krause et al. (2006) only two families remained in Africa during the Campanian-Mastrichtian, while 12 or 13 were present in South America during this time interval (six in Madagascar, nine in India). Small "reptiles" (squamates) cannot be taken into account because of the uncertain age of the rich locality Wadi Abu Hashim (Cenomanian or Maastrichtian). The diversity of amphibians also is low in the Campanian-Maastrichtian of Africa, it includes only one family (Gardner and Rage 2016) whereas at least five families are known from the same interval in South America (one in Madagascar and possibly seven in India; Rage et al., this volume).

However, it is presumed that the comparison of the Late Cretaceous African mammal faunas is biased by strong fossil gaps for this period in the African Island (Table 1). The comparison of the Paleogene mammal faunas of the African Island is likely more significant. From the published literature, we estimated that around 400 species of mammals are recorded for the whole Paleogene in Africa (Gheerbrant 2001, and EG's work in progress), which is noticeably low with respect to the Paleogene of North America (e.g., Woodburne 2004) and Europe (e.g., Aguilar et al. 1997). Estimation based on the Paleobiology Database (PalaeoDB, Fossilworks website) also shows a much lower (half) Paleogene mammal species diversity in Africa than in South America (Table 1). In addition, it should be recalled that the 
number of Paleogene African mammals includes species that originated from Laurasian immigrants (e.g., marsupials, rodents, simiiformes, anthracotheres). Amphibians are also less diverse in Africa than in South America during the Paleogene. Four to six families were reported from South America, whereas three or four are known from Africa. Squamates are the only exception because they appear as diverse in Africa as in South America during the Paleogene; in both continents about ten families were recovered, it being understood that African squamates also likely include Eurasian immigrants. 
Table 1. Number of Cretaceous and Paleogene species of vertebrates (all vertebrates, tetrapods, and mammals only) known in the Island Africa and South America as estimated from the Paleobiology Database (calculation made on the Fossilworks website). Note that, with the exception of mammals in the Early Cretaceous of South America (gap), diversity is lower in Africa than in South America. The tetrapods column shows that, with regard to South America, in Africa the number of species did not markedly increase between the Early and Late Cretaceous (despite probable arrival of immigrants), and that during the Paleogene the increase is more marked in Africa (due to immigrants and new AFS; see Fig. 5) but the numbers in Africa remain markedly lower. The recorded numbers of species for "vertebrates" (Cretaceous-Paleogene) and "mammals" (Cretaceous) are less significant because of inclusion of fishes and gaps, respectively.

\begin{tabular}{|c|c|c|c|c|c|c|c|c|c|}
\hline & \multicolumn{3}{|c|}{ Vertebrates } & \multicolumn{3}{|c|}{ Tetrapods } & \multicolumn{3}{|c|}{ Mammals } \\
\hline & $\begin{array}{l}\text { Island } \\
\text { Africa }\end{array}$ & $\begin{array}{l}\text { South } \\
\text { America }\end{array}$ & $\begin{array}{l}\text { \% Island } \\
\text { Africa }\end{array}$ & $\begin{array}{l}\text { Island } \\
\text { Africa }\end{array}$ & $\begin{array}{l}\text { South } \\
\text { America }\end{array}$ & $\begin{array}{l}\text { \% Island } \\
\text { Africa }\end{array}$ & $\begin{array}{l}\text { Island } \\
\text { Africa }\end{array}$ & $\begin{array}{l}\text { South } \\
\text { America }\end{array}$ & $\begin{array}{l}\text { \% Island } \\
\text { Africa }\end{array}$ \\
\hline $\begin{array}{l}\text { Early } \\
\text { Cretaceous }\end{array}$ & 64 & 289 & 60.38 & 55 & 84 & 65.47 & 13 & 1 & $\begin{array}{c}\text { (gap in } \\
\text { South } \\
\text { America) }\end{array}$ \\
\hline $\begin{array}{l}\text { Late } \\
\text { Cretaceous }\end{array}$ & 105 & 230 & 45.65 & 71 & 207 & 34.29 & 0 & 20 & $\begin{array}{l}\text { (gap in } \\
\text { Africa) }\end{array}$ \\
\hline Paleogene & 388 & 581 & 66.78 & 323 & 556 & 58.09 & 248 & 496 & 50 \\
\hline
\end{tabular}

Looking for the causes of the extinctions of the native African taxa leads to the search of unfavorable environmental conditions, more specifically to unfavorable climatic conditions. Unfortunately, there is no agreement about the climate of that time. Scotese et al. (1999) suggested that a large part of Africa was arid during the opening of South Atlantic 
(see also Burke et Sengor 1998), but Chaboureau et al. (2012) later reconstructed a wet climate for that time. Holz (2015) reported several episodes of warm greenhouse and "hothouse" at this time. Hothouse episodes were especially observed in the AptianTuronian. During the Late Turonian extremely hot temperatures $\left(>40^{\circ} \mathrm{C}\right)$ were reported in equatorial Atlantic areas (Bice et al. 2006); the Aptian and Cenomanian are indeed also time of extinction events in continental faunas (Holz 2015). High temperatures also strongly affected plant evolution during mid-Cretaceous (Mays et al. 2017). Therefore, climatic perturbations took place during the Cretaceous, more specifically during the first stages of African isolation. However, the above studies did not identify events that would have affected Africa only and cannot account for the African selective extinctions. Only Russell and Paesler (2003) noted events restricted to Africa. A major perturbation of the environment took place on the continent from the Barremian-Aptian to the SantonianCampanian and a strong disturbance of the environment in Africa impacted biotas. This event occurred during the separation of Africa from South America and at the times during which the native African fauna should have settled in the continent. However, it is acknowledged that the causes of low faunal density in Africa remain largely unknown.

Anyway, whatever the causes could have been, it clearly appears that the fauna was poor in the Island Africa, while at that time faunas of vertebrates markedly developed on other continents. The poor diversity of the African vertebrates, and especially of the African natives, likely explains the evolutionary success of several waves of dispersals that reached Island Africa from other continents, mainly from Laurasia.

\section{Colonization of Island Africa by newcomers (Figs. 4-5)}


Although geographically an island during the Late Cretaceous and Paleogene, the AraboAfrican plate was not completely isolated biologically. As far as biotic relations between Africa and other Gondwanan continents are concerned, potential filter routes connected Africa to South America, Madagascar and India. However, these routes did not entail significant Gondwanan arrivals in Africa (Gheerbrant and Rage 2006). On the contrary, they likely permitted or helped out of Africa dispersals. For example, rodent (caviomorphs) and primate (plathyrrines) mammals (Antoine et al. 2012; Bond et al. 2015) of African origin reached South America during the Eocene. In addition, based on molecular evidence, Vidal et al. (2008) suggested that amphisbaenian squamates dispersed similarly during the Eocene. Some dispersals, inferred from molecular phylogenies, also occurred between Africa and Madagascar; they involved reptilian taxa during the Late Cretaceous and "reptiles" and mammals (primates, afrotherians) during the Paleogene. Most of them were also likely outof-Africa dispersals (Gheerbrant and Rage 2006). Dispersals of vertebrates from Africa to India were suggested but are not demonstrated. The dispersal of adapisoriculid mammals from India to Africa (Prasad et al. 2010) appears to be the only argued dispersal from a Gondwanan continent to Africa.

Paradoxically, while relations with other Gondwanan continents were very limited, interchanges with Eurasia were developed. They took place on the Mediterranean Tethyan Sill (Fig. 1), a discontinuous terrestrial route on fragments of continental shelves, and were controlled by variations of the sea-level (Gheerbrant and Rage 2006). Excepting the mammals with Laurasian affinities from the earliest Cretaceous of Anoual-Ksar Metlili (Sigogneau-Russell 1991; Sigogneau-Russell et al. 1998; Kielan-Jaworowska et al. 2004), 
Cretaceous interchanges mainly involved "reptiles" and occurred in both directions, but during the Paleogene the interchanges were dominated by dispersals of mammals toward Africa. Several Paleogene mammals that came from Laurasia evolved as more or less successful endemic lineages in Africa; some of them have become important components of extant faunas, but others went extinct. Conversely, we know only a few examples of Paleogene African mammal taxa that colonized Laurasia such as the hyaenodontids (Solé et al. 2009).

We here focus on mammals because their fossil history is comparatively welldocumented and because their history in Africa has had considerable impact on the evolution of the living world. The most consensual hypothesis is that modern mammals (eutherians, placentals) are derived from Laurasian and especially Eurasian stem groups (Archibald 2003; Wible et al. 2007), and entered Island Africa owing to a series of successive trans-Tethyan dispersals. Gheerbrant $(1987,1990,2001)$ and Gheerbrant and Rage (2006) detected five to seven trans-Tethyan dispersal phases toward Africa from the Late Cretaceous or earliest Paleocene to the earliest Oligocene. These dispersal phases led to the immigration of several eutherian and placental taxa, which evolved more or less successfully in Africa and formed distinct successive African assemblages named African Faunal Strata. An African Faunal Stratum (AFS) includes the Laurasian immigrants and all issued lineages that subsequently evolved in Africa (Fig. 4) (Gheerbrant and Rage 2006). An AFS should not be confused with a biogeographical cohort as used by Gheerbrant (2001) and Beard (2016). A biogeographical cohort includes an assemblage of immigrant taxa issued from a single dispersal event and continental source (e.g., Gheerbrant 2001). An example is the biogeographical cohort of immigrant mammals of Asian origin which includes the simiiform 
primates and the hystricognath and possibly anomaluroid rodents (Marivaux et al. 2005, Coster et al. 2015) that entered Africa by the Middle/Late Eocene (Seiffert 2012; Beard 2016). An AFS can include a biogeographical cohort of immigrants of common geographical origin or different lineages with distinct origins (including those of the same biogeographical cohort).

\section{PLACE FIGURE 4 ABOUT HERE; WIDTH = 1.5 COLUMN}

It should be noted that in addition to the Paleogene AFS, earlier trans-Tethyan dispersals took place during the Mesozoic; the best known example corresponds to Laurasian mammal taxa from the Anoual Ksar Metlili locality such as the gobiconodontids (Sigogneau-Russell 2003) and the tribosphenidans. No other documented Cretaceous Laurasian dispersals in Africa are known by contrast to several reported Cretaceous out of Africa dispersals (e.g., Le Loeuff 1991; Pereda-Suberbiola 2009). As a consequence, the Jurassic and Cretaceous AFS (Fig. 5, AFS K1 and K2) remain nearly unknown. For the Late Cretaceous period, at least, this is probably related to the poor Mesozoic fossil record of Africa as mentioned above.

The most successful AFS significantly contributed to the modern fauna of Africa and, for some taxa, to the World fauna. For example, the earliest known placental dispersal that entered Africa (as documented by the Adrar Mgorn and Ouled Abdoun Paleocene faunas) was especially important since it was at the origin of the afrotherians (macroscelideans, tenrecoids, tubulidentates and paenungulates). It corresponds to an Early Paleocene or Late Cretaceous AFS that gave rise to some of the most spectacular endemic African radiations such as that of the hyracoid and proboscidean paenungulates (Fig. 6A). This AFS has been therefore prominent in the history of African faunas. In addition to extant taxa, this AFS 
includes extinct forms such as primitive eutherians (stem placentals: cimolestids, todralestids) (Gheerbrant 1992, Gheerbrant and Rage 2006). Molecular studies suggest a Late Cretaceous age for the afrotherian origin, but the exact age of the earliest African placentals remains a major challenge for current paleontological field research.

Subsequent dispersal phases and related AFS (Fig. 5, AFS P1-3) are at the origin of other extant famous endemic African mammal taxa. For instance, they explain the arrival from Asia of the simiiform primates in Africa in the Eocene (e.g., Beard 2004, 2016; Seiffert 2006, 2012), as part of the Lutetian/Bartonian or Bartonian/Priabonian dispersal phase and African Faunal Stratum. The first African simiiforms, from the Late Eocene, are basal to an endemic major African lineage from which evolved the cercopithecoids and hominoids and their stem-groups such as oligopithecids and propliopithecids (Fig. 6B) (Seiffert 2012). Earliest African rodents such as the zegdoumyids (Vianey-Liaud et al. 1994; Hartenberger et al. 1997) probably arrived earlier as part of the Thanetian/Ypresian AFS (Gheerbrant \& Rage 2006).

\section{PLACE FIGURE 5 ABOUT HERE; WIDTH = 2 COLUMNS (FULL PAGE WIDTH)}

Some of the lineages that evolved from the Paleogene AFS remained strictly endemic (hyracoids, macroscelids, chrysochlorids, anomalurids, catarrhine primates) to the Island Africa before the contact with Eurasia, but others succeeded in dispersing overseas out of the Island Africa (hyaenodontids toward Laurasia, embrithopods in south-eastern Europe and Turkey, stem platyrrhine primates and caviomorph rodents toward South America, tenrecids and lemuriforms toward Madagascar). 
Whatever the details of the history of the dispersals, the success of several taxa of Laurasian and mostly Eurasian origin that entered the Island Africa is striking and meaningful. It may be supposed that this flourishing evolutionary history was triggered and subsequently favored by the peculiar environmental conditions, including low diversity of vertebrate assemblages that prevailed in Africa at that time.

\section{Africa as a secondary cradle}

As stated above, Island Africa was depauperate after separation from South America. The poor diversity of the native fauna likely resulted in low competition pressure, and newcomers might have settled easily and subsequently evolved in favorable African ecosystems with free niches. This corresponds to the standard view about ecological opportunities, according to which an environment in which resources are underexploited, i.e. in vacant niches, favors adaptation of newcomers. Such conditions obviously occur in depauperate areas (Gheerbrant and Rage 2006; Gavrilets and Losos 2009). In addition, Gavrilets and Vose (2005) suggested that larger areas, which was the case of the Island Africa, favor colonization of niches and subsequent diversification of the emerging clade.

Therefore, both theoretical studies and paleontological observations converge to indicate that the Island Africa played the role of a secondary cradle for several major clades, including extant ones. Beard (2004) similarly pointed to this key evolutionary role of the insular Africa in his concept of the "African melting pot". Taxa of Laurasian origin entered Africa and found there favorable conditions, with a number of free ecological niches, to 
evolve locally, giving rise to new adaptive radiations. This process repopulated Africa, adding new taxa to the few native groups.

Aside from mammals, the role of Africa as a secondary cradle during isolation appears to have been significant for African testudinid turtles (Hofmeyr et al. 2016), an African unnamed clade of elapoid snakes (Kelly et al. 2009), and perhaps a large unnamed clade of colubrid snakes (McCartney et al. 2014). This list is certainly not exhaustive, but it emphasizes the evolutionary role of Africa at high taxonomic levels.

\section{The end of isolation of Africa}

It is generally acknowledged that massive continental faunal interchanges involving a large diversity of land mammals between Africa and Eurasia began during the Early Miocene, as a consequence of the closure of the Tethys (Cooke 1968; Coryndon and Savage 1973; Bernor et al. 1987; Van der Made 1999; Sen 2013). During the Late Oligocene, taxa that crossed the Tethys seaway were rare and the African mammal fauna remained widely endemic (Kappelman et al. 2003). The few known mammals crossing the Tethys during the Late Oligocene include an elephantoid from the Bugti Hills of Pakistan (Antoine et al. 2003) and a viverrid carnivore from Kenya (Rasmussen and Gutierrez 2009; Leakey et al. 2011). The latest trans-Tethyan interchanges with Africa likely took place in the area of the present contact when the two plates got closer together. This corresponds to the Iranian Route as reported by Gheerbrant and Rage (2006).

The disappearance of the marine barrier (closure of Tethys), replaced by a terrestrial contact between Africa and Eurasia ("Gomphotherium landbridge"; Rögl 1999), caused a 
marked geodispersal (sensu Lieberman and Eldredge 1996 ; Upchurch 2008) in both directions. This event took place during the Burdigalian (Bernor et al. 1987; Van der Made 1999; Mein 1999; Rögl 1999). Van der Made (1999) and Sen (2013) more precisely suggested a date close to $20 \mathrm{Ma}$ for the beginning of these interchanges. This event, which shaped the present mammal fauna of Africa, may be labelled the Great Old World Interchange (GOWI; Gheerbrant 2001) by analogy to the younger Great American Interchange (Stehli and Webb 1985; Woodburne 2010). It marks the end of isolation and endemicity in Africa, which is the end of the Island Africa.

The subsequent evolution of the endemic African fauna after the Great Old World Interchange (GOWI) is characterized by the survival and even success of a number of major African lineages in extant faunas. Among mammals they include the afrotherians, the primates (catarrhines and lemuriforms), and several rodents (hystricognaths and anomaluroids). The extant afrotherians includes six placental orders, among which the endemic African ungulates (hyracoids, proboscideans and sirenians). Some of these endemic lineages widely diversified out of Africa after the GOWI, such as the hyracoids, sirenians, proboscideans, tubulidentates and primates (catarrhines and lemuriforms). This is remarkable with respect to the evolution of other endemic continental faunas which are generally affected by important extinctions. For instance, in South America, which also experimented a long geographical isolation south of the Tethys, none of the ungulate orders (notoungulates, litopterns, astrapotheres, etc...) survived. However, other endemic South American lineages also successfully evolved in extant faunas (marsupials, xenarthrans, platyrrhines primates, caviomorph rodents), and even out of South America such as in North America (opossums) and in Australia (australidelphians, the main extant marsupial 
radiation). Of note, the platyrrhines primates and caviomorph rodents which represent major South American endemic extant clades are of African origin. Extinctions obviously also strongly affected the endemic African fauna after the closure of Tethys; among mammals this concerns many hyracoids (medium and large sized species), all the embrithopods, several lineages of primates and rodents, hyaenodontids, and ptolemaiids. However, the success of several other African endemic taxa out of Africa, especially the primates (catarrhines and lemuriforms), proboscideans, sirenians and hystricognath rodents, is a notable trait of the African evolution. This relative African success might be related in part to the peculiar biogeographical history of Africa. The Island Africa is characterized by repeated trans-Tethyan biotic relations with Laurasia (Fig. 5), which resulted in contacts between faunas that sustained an evolutionary competitive and adaptive dynamism among groups then living in Africa. It might account for the survival and success of several old African groups in living faunas.

The trans-Tethyan faunal relations of the Island Africa with Eurasia significantly contributed to the biogeographical pattern of the modern Old World Realm that definitely established by the closure of Tethys. The modern Old World faunal pattern, which largely results from a mix of African plus Eurasian faunas, has early biogeographical roots dating from the time of the trans-Tethyan dispersals.

\section{Conclusions}

From approximately the end of the Early Cretaceous to the Early Miocene, i.e. during about 80 million years, Africa was geographically isolated as a gigantic island. After the beginning of isolation and for poorly known reasons, the native continental fauna of Africa was poor, 
notably with respect to South America, the last continent linked to Africa; it resulted in the impression of a depauperate Island Africa. After the Cretaceous, the three key periods in vertebrate evolution in the Island Africa (Cretaceous-Paleogene (K-Pg), Paleocene-Eocene and Eocene-Oligocene) are either poorly documented (K-Pg event) or not marked by significant faunal turnovers in Africa, as far as we know. For instance, the mammal faunas from the Ouarzazate basin (Morocco) show faunal continuity at the Paleocene-Eocene boundary for several lineages of insectivoran-grade eutherian mammals (Gheerbrant et al. 1998). The Eocene-Oligocene biotic changes in Africa are best documented by the Fayum faunas in Egypt. The Fayum mammal assemblages, and especially the primates, show some changes at the Eocene-Oligocene boundary (e.g., Seiffert 2006, 2007, 2012), but those changes remain moderate with respect to, for instance, the faunal evolution in Europe that is marked at the same time by the "Grande Coupure" faunal revolution. The main changes in the African Paleogene faunas are in fact marked by immigrations of new Laurasian lineages.

Despite geographic isolation, intermittent and discontinuous emerged routes indeed permitted several Laurasian and especially Eurasian continental taxa to enter the Island Africa. Surprisingly, there is very little evidence of immigrations from other Gondwanan continents (Gheerbrant and Rage 2006). In the Island Africa, various Laurasian taxa of mainly Eurasian origin found favorable environmental conditions (low competition pressure, vacant ecological niches) and they settled and evolved successfully locally. Some of them gave rise to remarkable endemic adaptive radiations, which repopulated Africa in addition to the remaining native taxa, and they constitute important clades of the extant African fauna (e.g., afrotherians, catarrhine primates, hystricognath rodents) (Fig. 6). Thus, Island Africa acted as a secondary cradle, boosting the evolution of stem groups that came from Eurasia. One of 
the main issues of the peculiar history of Africa is indeed that all Cenozoic African mammals

(including living ones) are derived from Laurasian stem groups, that evolved locally in several AFS (Figs. 4-5).

\section{PLACE FIGURE 6 ABOUT HERE; WIDTH = 1 COLUMN}

The evolutionary history of African faunas is also characterized by the relative success of the endemic taxa, in particular after the Great Old World Interchange that followed the establishment of the definite terrestrial contact with Eurasia by the Early Miocene. Not only a significant number of endemic African clades survived up to today, but some of them went out of Africa and spread successfully over other continents. This African evolutionary success was likely sustained by the precocious contacts between faunas of the Island Africa and of Eurasia. These early Eurasian-African trans-Tethyan relations prefigure the paleobiogeographic pattern of the modern Old World fauna. They constitute the periTethyan roots of the modern Old World fauna which established after the closure of the Tethys.

Acknowledgements. Jean-Claude Rage, who initiated this paper, sadly suddenly passed away after submission of our manuscript. The notion of a depauperate native African fauna was an old idea of Jean-Claude that stimulated the writing of this paper. EG dedicates posthumally this work to the honour and memory of our dear colleague and friend, Jean Claude. The authors dedicate this paper to Professor Ashok Sahni whose activity in India has significantly impacted our knowledge of Gondwanan vertebrates. We thank R. Patnaik and G.V.R. Prasad for having invited us to contribute to this volume. We thank the editors and the two reviewers for their very useful comments and corrections which helped to improve our manuscript. Thanks are due also to $C$. Letenneur (CR2P, MNHN) who made the figures 2, 4, 5, 6. 


\section{References}

Aguilar, J.P., \& Michaux, J. (Eds.). (1997). BiochroM'97. Mémoires et Travaux de l'Ecole Pratique des Hautes Etudes, Institut de Montpellier 21.

Antoine, P.O., Welcomme, J.L., Marivaux, L., Baloch, I., Benammi, M., \& Tassy, P. (2003). First record of Paleogene Elephantoidea (Mammalia, Proboscidea) from the Bugti Hills of Pakistan. Journal of Vertebrate Paleontology, 23, 977-980.

Antoine, P.O., Marivaux, L., Croft, D.A., Billet, G., Ganerød, M., Jaramillo, C., Martin, T., Orliac, M.J., Tejada, J., Altamirano, A.J., Duranthon, F., Fanjat, G., Rousse, S., \& Gismondi, R.S. (2012). Middle Eocene rodents from Peruvian Amazonia reveal the pattern and timing of caviomorph origins and biogeography. Proceedings of the Royal Society $B, 279,1319-1326$.

Apesteguía, S., Daza, J.D., Simões, T.R., \& Rage, J.C. (2016). The first iguanian lizard from the Mesozoic of Africa. Royal Society Open Science, 3, 160462.

Archibald, J.D. (2003). Timing and biogeography of the eutherian radiation: fossils and molecules compared. Molecular Phylogenetics and Evolution, 28, 350-359.

Averianov, A.O., Archibald, J.D., \& Martin, T. (2003). Placental nature of the alleged marsupial from the Cretaceous of Madagascar. Acta Palaeontologica Polonica, 48, 149151.

Beard, K.C. (2004). The Hunt for the Dawn Monkey: Unearthing the Origins of Monkeys, Apes, and Humans. Berkeley: University California. Press.

Beard, K.C. (2016). Out of Asia: anthropoid origins and the colonization of Africa. Annual Review of Anthropology, 45, 199-213. 
Bernor, R.L., Brunet, M., Ginsburg, L., Mein, P., Pickford, M., Rögl, F., Sen, S., Steininger, F., \& Thomas, H. (1987). A consideration of some major topics concerning Old World Miocene mammalian chronology, migrations and paleogeography. Geobios, 20, 431-439.

Bice, K.L., Birgel, D., Meyers, P.A., Dahl, K.A., Hinrichs, K.U., \& Norris, R.D. (2006). A multiple proxy and model study of Cretaceous upper ocean temperatures and atmospheric CO2 concentrations. Paleoceanography, 21, PA2002.

Bond, M., Tejedor, M.F., Campbell Jr, K.E., Chornogubsky, L., Novo, N., \& Goin, F. (2015). Eocene primates of South America and the African origins of New World monkeys. Nature, 520, 538-541.

Burke, K., \& Sengör, A.M.C. (1988). Ten metre global sea-level change associated with South Atlantic Aptian salt deposition. Marine Geology, 83, 309-312.

Carvalho, M.S.S., \& Maysey, J.G. (2008). New occurrence of Mawsonia (Sarcopterygii: Actinistia) from the Early Cretaceous of the Sanfranciscana Basin, Minas Gerais, southeastern Brazil. In L. Cavin, A. Longbottom \& M. Richter (Eds.), Fishes and the Breakup of Pangaea. Geological Society, London, Special Publications, 295, 109-144.

Chaboureau, A.C., Donnadieu, Y., Sepulchre, P., Robin, C., Guillocheau, F., \& Rohais, S. (2012). The Aptian evaporites of the South Atlantic: a climatic paradox? Climate of the Past, 8, 1047-1058.

Chornogubsky, L. (2011). New remains of the dryolestoid mammal Leonardus cuspidatus from the Los Alamitos Formation (Late Cretaceous, Argentina). Paläontologische Zeitschrift, 85, 343-35. 
Cione, A.L., Gouiric, S., Goin, F., \& Poiré, D. (2007). Atlantoceratodus, a new genus of lungfish from the upper Cretaceous of South America and Africa. Revista del Museo de La Plata, Paleontología, 10, 1-12.

Cooke, H.B.S. (1968). The Fossil Mammal Fauna of Africa. Quarterly Review of Biology, 43, 234-264.

Coryndon, S.C., \& Savage, R.J.G. (1973). The origin and affinities of African mammal faunas. In N.F. Hughes (Ed.), Organisms and Continents through Time. Paleontological Association of London, Special Papers in Palaeontology, 12, 121-135.

Coster, P. M. C., Beard, K. C., Salem, M. J., Chaimanee, Y., \& Jaeger, J.-J. (2015). New fossils from the Paleogene of central Libya illuminate the evolutionary history of endemic African anomaluroid rodents. Frontiers in Earth Science, 3 , 56, 51-15.

Dos Reis, M., Inoue, J., Hasegawa, M., Asher, R.J., Donoghue, P.C., \& Yang, Z. (2012). Phylogenomic datasets provide both precision and accuracy in estimating the timescale of placental mammal phylogeny. Proceedings of the Royal Society B, 279, 3491 .

Eberle, J., Fabrizi, S., Lago, P., \& Ahrens, D. (2017). A historical biogeography of megadiverse Sericini - another story "out of Africa"? Cladistics, 33, 183-197.

Elewa, A.M.T. (2017). Ostracod provincialism and migration as a response to movements of Earth's plates: Cretaceous-Paleogene ostracods of West Africa, North Africa and the Middle East. Journal of African Earth Sciences, 134, 92-105.

Ezcurra, M.D., \& Agnolín, F.L. (2012). A new global palaeobiogeographical model for the Late Mesozoic and Early Tertiary. Systematic Biology 61, 553e566.

Fossilworks website. http://fossilworks.org (accessed January 2018). 
Frazão, A., da Silva, H.R., \& Moraes Russo, C.A. de (2015). The Gondwana breakup and the history of the Atlantic and Indian Oceans unveils two new clades for early neobatrachian diversification. PLOS ONE, 10, e0143926.

Gaffney, E.S., Tong, H., \& Meylan, P.A. (2006). Evolution of the side-necked turtles: The families Bothremydidae, Euraxemydidae, and Araripemydidae. Bulletin of the American Museum of Natural History, 300, 1-318.

Gardner, J.D., \& Rage, J.C. (2016). The fossil record of lissamphibians from Africa, Madagascar, and the Arabian Plate. In J.D. Gardner \& T. Přikryl (Eds.), Contributions in honour of Zbyněk Roček. Palaeobiodiversity and Palaeoenvironments, 96, 169-220.

Gavrilets, S., \& Losos, J.B. (2009). Adaptive radiation: Contrasting theory with data. Science, $323,732-737$.

Gavrilets, S., \& Vose, A. (2005). Dynamic patterns of adaptive radiation. Proceedings of the National Academy of Sciences, 102, 18040-18045.

Gheerbrant, E. (1987). Les Vertébrés continentaux de l'Adrar Mgorn (Maroc, Paléocène); une dispersion de mammifères transtéthysienne aux environs de la limite Mesozoïque/Cénozoïque? Geodinamica Acta, 1, 233-246.

Gheerbrant, E. (1990). On the early biogeographical history of the African Placentals. Historical Biology, 4, 107-116.

Gheerbrant, E. (1992). Les mammifères paléocènes du Bassin d'Ouarzazate (Maroc). I. Introduction générale et Palaeoryctidae. Palaeontographica A, 224, 67-132.

Gheerbrant, E. (2001). Histoire paléobiogéographique des mammifères paléogènes du domaine arabo-africain (vol. I). Base de données et listes fauniques des mammifères du 
Paléogène arabo-africain et bibliographie (Vol. II). Rapport d'activités (Vol. III). Mémoire d'Habilitation à Diriger des Recherches, Université Pierre et Marie Curie, Paris.

Gheerbrant, E., \& Rage, J.C. (2006). Paleobiogeography of Africa: How distinct from Gondwana and Laurasia? Palaeogeography, Palaeoclimatology, Palaeoecology, 241, 224-246.

Gheerbrant, E., Sudre, J., Sen, S., Abrial, C., Marandat, B., Sigé, B. \& Vianey-Liaud, M. (1998). Nouvelles données sur les mammifères du Thanétien et de I'Yprésien du bassin d'Ouarzazate (Maroc) et leur contexte stratigraphique. Palaeovertebrata, 27, 155-202.

Goin, F.J., Woodburne, M.O., Zimicz, A.N., Martin, G.M., \& Chornogubsky, L. (2016). A brief history of South American metatherians. Dordrecht: Springer.

Gorscak, E., \& O`Connor, P.M. (2016). Time-calibrated models support congruency between Cretaceous continental rifting and titanosaurian evolutionary history. Biology Letters, 12, 20151047.

Gorscak, E., O'Connor, P.M., Roberts, E.M., \& Stevens, N.J. (2017). The second titanosaurian (Dinosauria: Sauropoda) from the Middle Cretaceous Galula Formation, Southwestern Tanzania, with remarks on African titanosaurian diversity. Journal of Vertebrate Paleontology, 37, e1343250.

Gottfried, M.D., Stevens, N.J., Roberts, E.M., O'Connor, P.M., \& Chami, R. (2009). A new Cretaceous lungfish from the Rukwa Rift Basin, Tanzania. African Natural History, 5, 3136.

Granot, R., \& Dyment, J. (2015). The Cretaceous opening of the South Atlantic Ocean. Earth and Planetary Science Letters, 414, 156-163. 
Hartenberger, J.L., Crochet, J.Y., Martinez, C., Feist, M., Godinot, M., Mannai Tayech, B., Marandat, B., \& Sigé, B. (1997). Le gisement de mammifères de Chambi (Éocène, Tunisie centrale) dans son contexte géologique. Apport à la connaissance de l'évolution des mammifères en Afrique. Mémoires et Travaux de l'Ecole Pratique des Hautes Etudes, Institut de Montpellier, 21, 263-274.

Heine, C., Zoethout, J. \& Müller, R. D. (2013). Kinematics of the South Atlantic rift. Solid Earth, 4, 215-253, doi:10.5194/se-4-215-2013

Hofmeyr, M.D., Vamberger, M., Branch, W., Schleicher, A., \& Daniels, S.R. (2016). Tortoise (Reptilia, Testudinidae) radiations in Southern Africa from the Eocene to the present. Zoologica Scripta, 46, 389-400.

Holz, M. (2015). Mesozoic paleogeography and paleoclimate - a discussion of the diverse greenhouse and hothouse conditions of an alien world. Journal of South American Earth Sciences, 61, 91-107.

Huttenlocker, A. K., Huttenlocker, A.D., Grossnickle, D.M., Kirkland, J.I., Schultz, J.A., \& Luo, Z.X. (2018). Late-surviving stem mammal links the lowermost Cretaceous of North America and Gondwana. Nature, 558, 108-112.

Jacobs, L.L., Polcyn, M.J., Mateus, O., Schulp, A.S., Gonçalves, A.O., \& Morais, M.L. (2016). Post-Gondwana Africa and the vertebrate history of the Angolan Atlantic Coast. Memoirs of Museum Victoria, 74, 343-362.

Kappelman, J., Rasmussen, D.T., Sanders, W.S., Feseha, M., Bown, T., Copeland, P., et al. (2003). Oligocene mammals from Ethiopia and faunal exchange between Afro-Arabia and Eurasia. Nature, 426, 549-552. 
Kelly, C.M.R., Barker, N.P., Villet, M.H., \& Broadley, D.G. (2009). Phylogeny, biogeography and classification of the snake superfamily Elapoidea: a rapid radiation in the late Eocene. Cladistics, 25, 38-63.

Kielan-Jaworowska, Z. (1992). Interrelationships of Mesozoic mammals. Historical Biology, 6, 185-201.

Kielan-Jaworowska, Z., Cifelli, R.L., \& Luo, Z.X. (2004). Mammals from the Age of Dinosaurs. New York: Columbia University Press.

Krause, D.W. (2001). Fossil molar from a Madagascan marsupial. Nature, 412, 497-498.

Krause, D.W., Prasad, G.V.R., Koenigswald, W., Sahni, A., \& Grine, F.E. (1997).

Cosmopolitanism among Gondwanan Late Cretaceous mammals. Nature, 390, 504-507.

Krause, D.W., O'Connor, P.M., Curry Rogers, K., Sampson, S.D., Buckley, G.A., \& Rogers, R.R. (2006). Late Cretaceous terrestrial vertebrates from Madagascar: Implications for Latin American biogeography. Annals of the Missouri Botanical Garden, 93, 178-208.

Leakey, M., Grossman, A., Gutiérrez, M., \& Fleagle, J.G. (2011). Faunal change in the Turkana Basin during the late Oligocene and Miocene. Evolutionary Anthropology, 20, 238-253.

Le Loeuff, J. (1991). The Campano-Maastrichtian vertebrate faunas from southern Europe and their relationships with other faunas in the world; palaeobiogeographical implications. Cretaceous Research, 12, 93-114.

Le Loeuff, J., Métais, E., Dutheil, D.B., Rubino, J.L., Buffetaut, E., Lafont, F., Cavin, L., Moreau, F., Tong, H., Blanpied, C., \& Sbeta, A. (2010). An Early Cretaceous vertebrate assemblage from the Cabao Formation of NW Libya. Geological Magazine, 147, 750-759.

Lieberman, B.S., \& Eldredge, N. (1996). Trilobite biogeography in the Middle Devonian: geological processes and analytical methods. Paleobiology, 22, 66-79. 
Luo, Z.X., Cifelli, R.L., Kielan-Jaworowska, Z. (2001). Dual origin of tribosphenic mammals. Nature, 409, 53-57.

van der Made, J. (1999). Intercontinental relationship Europe-Africa and the Indian Subcontinent. In G. Rössner \& K. Heissig (Eds.), The Miocene Land Mammals of Europe (pp. 457-472). Munich: F. Pfeil.

Marivaux, L., Adnet, S., Benammi, M., Tabuce, R., \& Benammi, M. (2017). Anomaluroid rodents from the earliest Oligocene of Dakhla, Morocco, reveal the long-lived and morphologically conservative pattern of the Anomaluridae and Non anomaluridae during the Tertiary in Africa. Journal of Systematic Palaeontology, 15:7, 539-569, DOI: $10.1080 / 14772019.2016 .1206977$

Mays, C., Cantrill, D.J., \& Bevitt, J.J. (2017). Polar wildfires and conifer serotiny during the Cretaceous global hothouse. Geology, 45, 1119-1122.

McCartney, J.A., Stevens, N.J., \& O'Connor, P.M. (2014). The earliest colubroid-dominated snake fauna from Africa: Perspectives from the Late Oligocene Nsungwe Formation of Southwestern Tanzania. PLoS ONE, 9, e90415.

Mein, P. (1999). Biochronologie et phases de dispersion chez les vertébrés cénozoïques. Bulletin de la Société géologique de France, 170, 195-204.

Nessov, L.A., Zhegallo, V.I., \& Averianov, A.O. (1998). A new locality of Late Cretaceous snakes, mammals and other vertebrates in Africa (western Libya). Annales de Paléontologie, 84, 265-274.

Novas, F.E., Valais, S. de, Vickers-Rich, P., \& Rich, T. (2005). A large Cretaceous theropod from Patagonia, Argentina, and the evolution of carcharodontosaurids. Naturwissenschaften, 92, 226-230. 
O'Connor, P.M., Gottfried, M.D., Stevens, N.J., Roberts, E.M., Ngasala, S., Kapilima, S., \& Chami, R. (2006). A new vertebrate fauna from the Cretaceous Red Sandstone Group, Rukwa Rift Basin, southwestern Tanzania. Journal of African Earth Sciences, 44, 277-288.

Oliveira, F.B., Molina, E.C., Marroig, G. (2009). Paleogeography of the South Atlantic: a route for primates and rodents into the new world? In Garber, P.A., Estrada, A., BiccaMarques, J.C., Heymann, E.W., \& Strier K.B. (eds). South American primates: comparative perspectives in the study of behavior, ecology, and conservation (pp. 5568). New York, NY: Springer New York.

Parmar, V., Prasad, G.V.R, \& Kumar, D. (2015). An overview of Jurassic mammalian fauna of India. In Y. Zhang, S.Z. Wu \& G. Sun (Eds.), 12th Symposium on Mesozoic Terrestrial Ecosystems (pp. 17-20). Shenyang.

Pereda-Suberbiola, X. (2009). Biogeographical affinities of Late Cretaceous continental tetrapods of Europe: a review. Bulletin de la Société géologique de France, 180, 57-71. Poropat, S.F., Mannion, P.D., Upchurch, P., Hocknull, S.A., Kear, B.P., Kundrát, M., Tischler, T.R., Sloan, T., Sinapius, G.H.K., Elliott, J.A., \& Elliott, D.A. (2016). New Australian sauropods shed light on Cretaceous dinosaur palaeobiogeography. Scientific Reports, 6, 34467.

Prasad, G.V.R., Verma, O., Gheerbrant, E., Goswami, A., Khosla, A., Parmar, V., \& Sahni, A. (2010). First mammal evidence from the Late Cretaceous of India for biotic dispersal between India and Africa at the KT transition. Comptes Rendus Palevol, 9, 63-71.

Rage, J.C. (2003). Relationships of the Malagasy fauna during the Late Cretaceous: Northern or Southern routes? Acta Palaeontologica Polonica, 48, 661-662. 
Rage, J.C., \& Cappetta, H. (2002). Vertebrates from the Cenomanian, and the geological age of the Draa Ubari fauna (Libya). Annales de Paléontologie, 88, 79-84.

Rage, J.C., Prasad, G.V.R., Verma, O., Khosla, A., \& Parmar, V. (xxxx). Anuran lissamphibians and squamate reptiles from Upper Cretaceous (Maastrichtian) Deccan Intertrappean sites in Central India, with a review of a lissamphibian and squamate diversity in the northward drifting Indian Plate. In G.V.R. Prasad \& R. Patnaik (Eds.), Biological consequences of break-up, isolation and drifting apart of former Gondwanaland continents. Cham: Springer.

Rasmussen, D.T., \& Gutierrez, M. (2009). A mammalian fauna from the late Oligocene of northwestern Kenya. Palaeontographica A, 288, 1-52.

Rögl, F. (1999). Mediterranean and Paratethys. Facts and hypotheses of an Oligocene to Miocene paleogeography. Geologica Carpathica, 50, 339-349.

Rougier, G., Gaetano, L., Drury, B.R., Colella, R., Gomez, R.O., \& Arango, P.N. (2011). A review of the Mesozoic mammalian record of South America. In J. Calvo, J. Porfiri, B. González Riga \& D. Dos Santos (Eds.), Paleontologia y dinosaurios desde America Latina (pp. 195214). Mendoza: Ediunc.

Russell, D.A., \& Paesler, M.A. (2003). Environments of mid-Cretaceous Saharan dinosaurs. Cretaceous Research, 24, 569-588.

Scotese, C.R. (2016). PALEOMAP PaleoAtlas for GPlates and the PaleoData Plotter Program, PALEOMAP Project, http://www.earthbyte.org/paleomap-paleoatlas-for-gplates/ Scotese, C.R., Boucot, A.J., \& McKerrow, W.S. (1999). Gondwanan palaeogeography and palaeoclimatology. Journal of African Earth Sciences, 28, 99-114. 
Seiffert, E.R. (2006). Revised age estimates for the later Paleogene mammal faunas of Egypt and Oman. Proceedings of the National Academy of Sciences, 103, 5000 -5005.

Seiffert, E.R. (2007). Evolution and extinction of Afro-Arabian primates near the EoceneOligocene boundary. Folia Primatologica, 78, 314-327.

Seiffert, E.R. (2012). Early primate evolution in Afro-Arabia. Evolutionary Anthropology, 21, 239-253.

Sen, S. (2013). Dispersal of African mammals in Eurasia during the Cenozoic: Ways and whys. Geobios, 46, 159-172.

Sereno, P.C., Wilson, J.A., \& Conrad, J.L. (2004). New dinosaurs link southern landmasses in the mid-Cretaceous. Proceedings of the Royal Society B, 271, 1325-1330.

Sereno, P.C., \& ElShafie, S.J. (2013). A new long-necked turtle, Laganemys tenerensis (Pleurodira: Araripemydidae), from the Elrhaz Formation (Aptian-Albian) of Niger. In D. Brinkman, P. Holroyd \& J. Gardner (Eds.), Morphology and evolution of turtles (pp. 215250 ). Dordrecht: Springer.

Seton, M., Müller, R.D., Zahirovic, S., Gaina, C., Torsvik, T., Shephard, G., Talsma, A., Gurnis, M., Turner, M., Maus, S., \& Chandler, M., (2012). Global continental and ocean basin reconstructions since 200 Ma. Earth-Science Reviews, 113, 212-270.

Sigogneau-Russell, D. (1991). Découverte du premier mammifère tribosphénique du Mésozoïque africain. Comptes rendus de l'Académie des Sciences de Paris II, 313, 16351640.

Sigogneau-Russell, D. (2003). Diversity of triconodont mammals from the Early Cretaceous of North Africa - affinities of the amphilestids. Palaeovertebrata, 32, 27-55. 
Sigogneau-Russell, D., Evans, S.E., Levine, J.F., \& Russell, D.A. (1998). The Early Cretaceous microvertebrate locality of Anoual, Morocco: A glimpse at the small vertebrate assemblages of Africa. Pp. 177-181. In S.G. Lucas, J.I. Kirkland \& J.W. Estep (Eds.), Lower and middle Cretaceous terrestrial ecosystems. New Mexico Museum of Natural History and Science Bulletin, 14, 177-181.

Sigogneau-Russell, D., Hooker, J.J., \& Ensom, P.C. (2001). The oldest tribosphenic mammal from Laurasia (Purbeck Limestone Group, Berriasian, Cretaceous, UK) and its bearing on the 'dual origin' of Tribosphenida. Comptes rendus de l'Académie des Sciences, 333, 141147.

Simões, T.R., Wilner, E., Caldwell, M.W., Weinschütz, L.C., \& Kellner, A.W.A. (2015). A stem acrodontan lizard in the Cretaceous of Brazil revises early lizard evolution in Gondwana. Nature Communications, 6, 8149.

Solé, F., Gheerbrant, E., Amaghzaz, M. \& Bouya, B. (2009). Further evidence of the African antiquity of hyaenodontid ("Creodonta", Mammalia) evolution. Zoological Journal of the Linnean Society 156(4), 827-846.

Stehli, F.G., \& Webb, S.D. (Eds.). (1985). The Great American Biotic Interchange. New York: Plenum Press.

Turner, A.H. (2006). Osteology and phylogeny of a new species of Araripesuchus (Crocodyliformes: Mesoeucrocodylia) from the Late Cretaceous of Madagascar. Historical Biology, 18, 255-369.

Upchurch, P. (2008). Gondwanan break-up: legacies of a lost world? Trends in Ecology and Evolution, 23, 229-236. 
Upchurch, P., Hunn, C.A., \& Norman, D.B. (2002). An analysis of dinosaurian biogeography: evidence for the existence of vicariance and dispersal patterns caused by geological events. Proceedings of the Royal Society B, 269, 613-621.

Vianey-Liaud, M., Jaeger, J.J., Hartenberger, J.L., \& Mahboubi, M. (1994). Les rongeurs de I’Eocène d'Afrique nord-occidentale (Glib Zegdou (Algérie) et Chambi (Tunisie)) et I'origine des Anomaluridae. Palaeovertebrata, 23, 93-118.

Vidal, N., Azvolinsky, A., Cruaud, C., \& Hedges, S.B. (2008). Origin of tropical American burrowing reptiles by transatlantic rafting. Biology Letters, 4, 115-118.

Wible, J.R., Rougier, G.W., Novacek, M.J., \& Asher, R.J. (2007). Cretaceous eutherians and Laurasian origin for placental mammals near the K/T boundary. Nature, 447, 1003-1006.

Woodburne, M.O. (Ed.). (2004) Late Cretaceous and Cenozoic mammals of North America. New York: Columbia University Press.

Woodburne, M.O. (2010). The Great American Biotic Interchange: Dispersals, tectonics, climate, sea level and holding pens. Journal of Mammalian Evolution, 17, 245-264.

Woodburne, M.O., \& Case, J.A. (1996). Dispersal, vicariance, and the Late Cretaceous to Early Tertiary land mammal biogeography from South America to Australia. Journal of Mammalian Evolution, 3, 121-161. 


\section{Figures caption}

Fig. 1. Paleogeographic map for the K-Pg boundary showing the isolated Arabo-African plate forming the Island Africa. The Island Africa existed for ca. $90 \mathrm{Ma}$, from the Aptian/Albian to the Oligocene/Miocene transitions. The Mediterranean Tethyan Sill corresponds to a series of partly emerged continental platforms, such as the Apulian plate, that were located intermediate between Eurasia and Africa across the Tethyan area and that acted as filtering intercontinental dispersal routes for terrestrial vertebrates during episodes of low eustatic levels (e.g., Gheerbrant \& Rage 2006). Paleogeographic map from The PALEOMAP PaleoAtlas (Scotese 2016).

Fig. 2. Diagrammatic view of the origin and evolution of the native African fauna. Several vicariant lineages evolved in Africa from the West Gondwanan stock, following the South Atlantic oceanic opening. They constitute the native African fauna (autochthonous fauna). The African fossil record documents a poor diversity of the African natives and a depauperate African Island. It raises the hypothesis that the African natives were affected by several significant extinction events during their evolutionary history. One or several extinction events (K1 and K2 in Fig.2) are in particular postulated during the Cretaceous in Africa, in addition to the K-Pg event; a middle Cretaceous extinction event (K1) is especially suggested in relation to the climatic hothouse events reported at this time, when South America and Africa began to drift apart (see text).

Fig. 3. Known Late Cretaceous and Paleogene localities with continental vertebrates. Data from Paleobiology Database and maps reconstructed on the Fossilworks website. A. Late Cretaceous terrestrial vertebrate localities. B. Late Cretaceous mammal localities. C. Paleogene terrestrial vertebrate localities. D. Paleogene mammal localities (including 
marine taxa). The rarity of the Cretaceous and Paleogene vertebrate sites in Africa provide a good picture of the general poor African fossil record. It should be noted that maps $A$ and $B$ do not show (data missing in the Paleobiology Database) the Cenomanian Libyan locality Draa Ubari that yielded the only known late Cretaceous mammal in Africa (Nessov et al. 1998).

Fig. 4. Diagrammatic explanation of an African Faunal Stratum (AFS). At time T1, mammals of Laurasian origin crossed the Tethys and settled in Africa. From the various immigrant stem species several African lineages (L1-4) emerged and evolved. Some of them (L1-2) became extinct, others (L3-4) reach the Present (TO) and are part of extant African faunas. The old Laurasian immigrants and all issued lineages that evolved in Africa made up the AFS (here AFS T1).

Fig. 5. Diagram summarizing the paleobiogeographical processes at the origin of the composition and evolutionary history of the continental fauna in the Island Africa. Several vicariant lineages evolved as the native fauna and were filtered over time by an unknown number extinctions, some being presumed local events (e.g., Late Cretaceous K1 and K2 extinction events in Fig. 2) and some being more global (K-Pg event); few of them crossed the K-Pg boundary, which resulted in vacant ecological niches. Aside from the native lineages, a significant number of old Laurasian immigrant lineages, most coming from Eurasia, crossed the Tethys and entered Africa at different times; they took advantage of local conditions and evolved forming successive African Fauna Strata during the Cretaceous (AFS K1-2) and the Paleogene (AFS P1-3). The Paleogene AFS (five to seven identified Paleogene AFS; see text and Gheerbrant and Rage 2006) are much better documented by the African fossil record than the Cretaceous AFS. These AFS evolved 
more or less successfully. Some include major African radiations that are still present in extant faunas, such as afrotherians, paenungulates (hyraxes and proboscideans), hyaenodonts, catarrhines primates, and hystricognath rodents. Others went extinct either in the Paleogene or in the Neogene (e.g., hyaenodonts). By the end of the Paleogene, the endemic African fauna resulted from the addition of the poor native fauna and taxa issued from the evolution of the different AFS (i.e., the descendants of old Laurasian immigrants). The extant African fauna results from the addition to this endemic fauna of the Eurasian taxa that colonized Africa after the closure of the Tethys at the OligoceneMiocene transition.

Fig. 6. Illustration of some remarkable taxa of the endemic mammal fauna from the Island Africa. A. Reconstruction of the stem proboscidean Phosphatherium from the Earliest Eocene (55 Ma) of Morocco. Phosphatherium belongs to the oldest confirmed faunal stratum from Africa including placental mammals: the Late Cretaceous/early Paleocene African Faunal Stratum (AFS) which is at the origin of the afrotherians (see text). B. Reconstruction of Aegyptopithecus, an early African stem catarrhine simiiform primates known from the Early Oligocene (30 Ma) of the Fayum in Egypt. Aegyptopithecus belongs to a later AFS, the Bartonian/Priabonian African Faunal Stratum that leads to colonization of the Island Africa by simiiform primates, following a trans-Tethyan dispersal from Asia (reconstructions by C. Letenneur). 


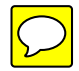
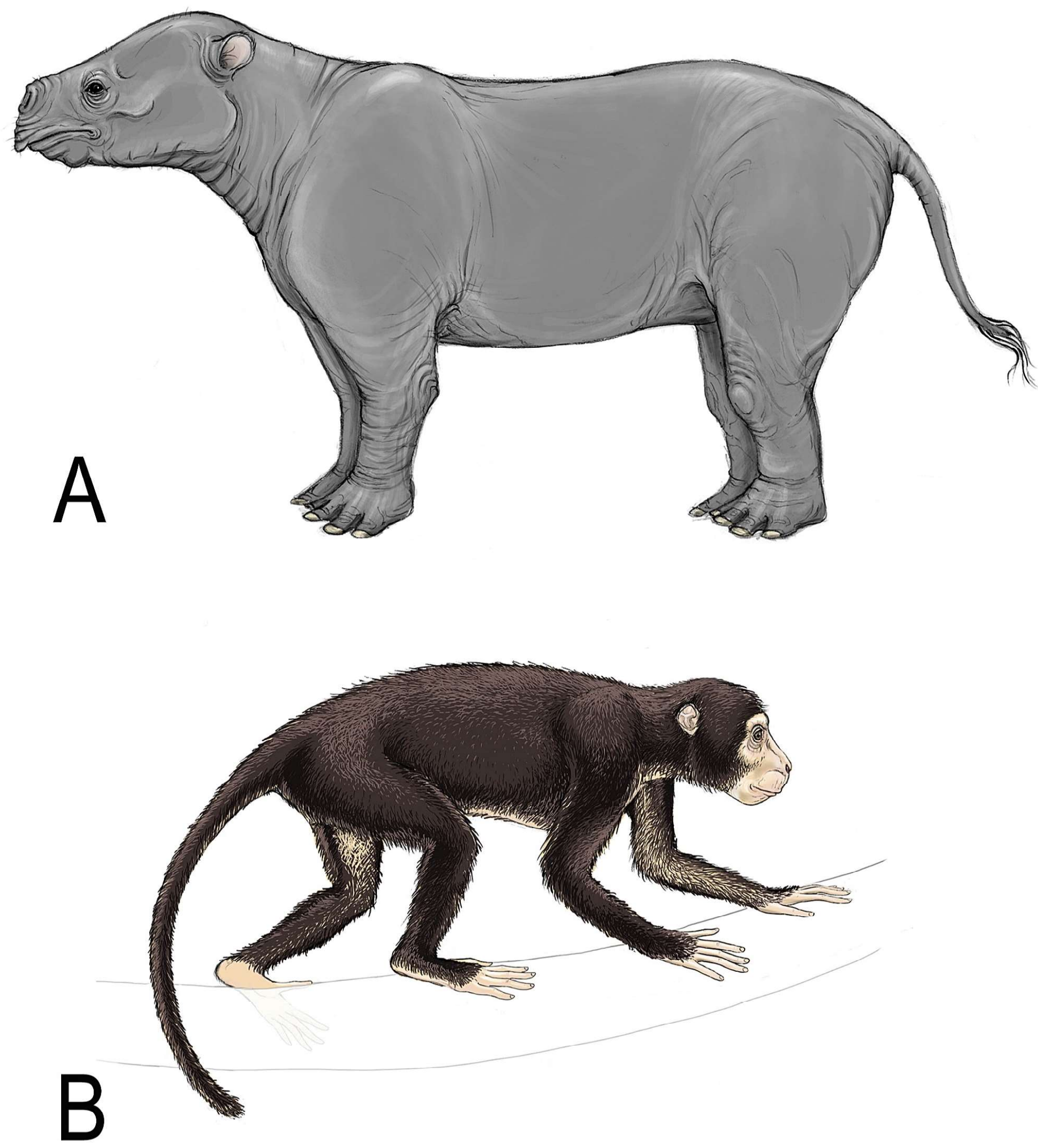
(2)

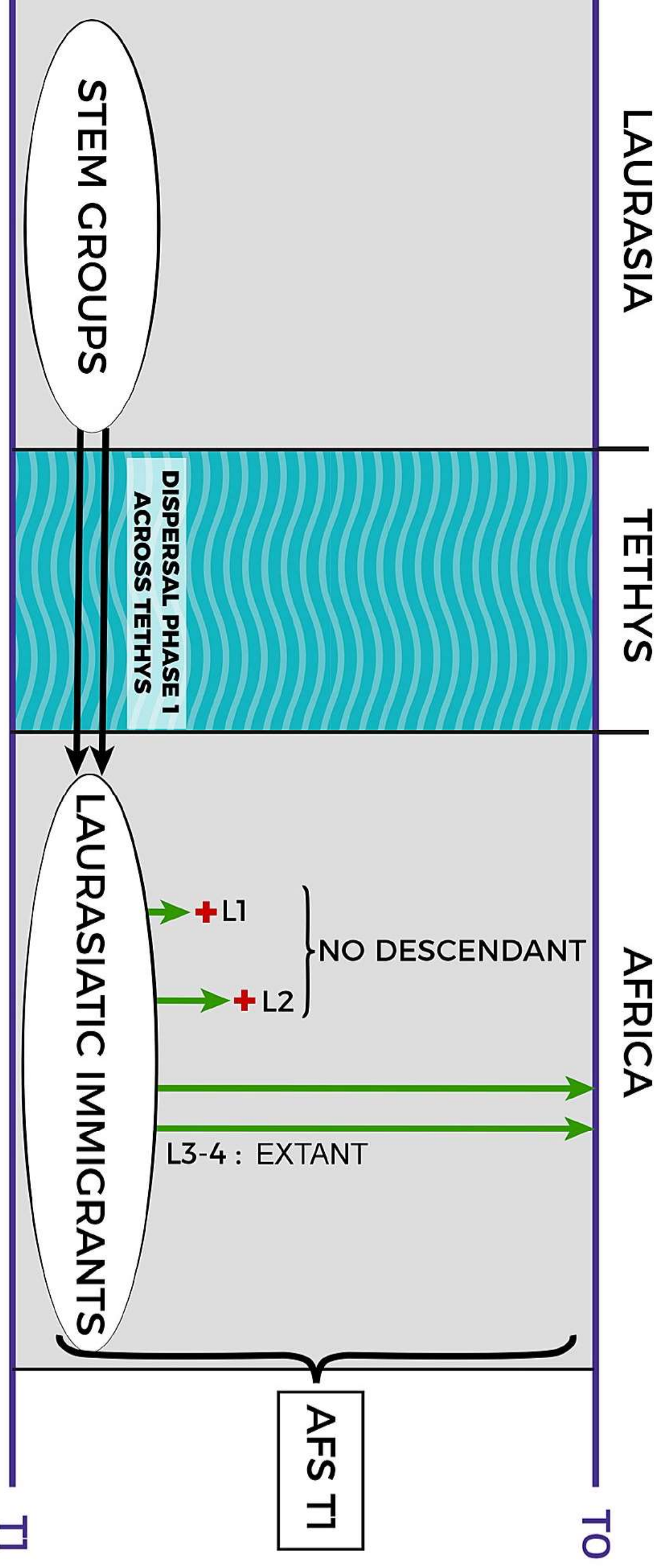


(2) 


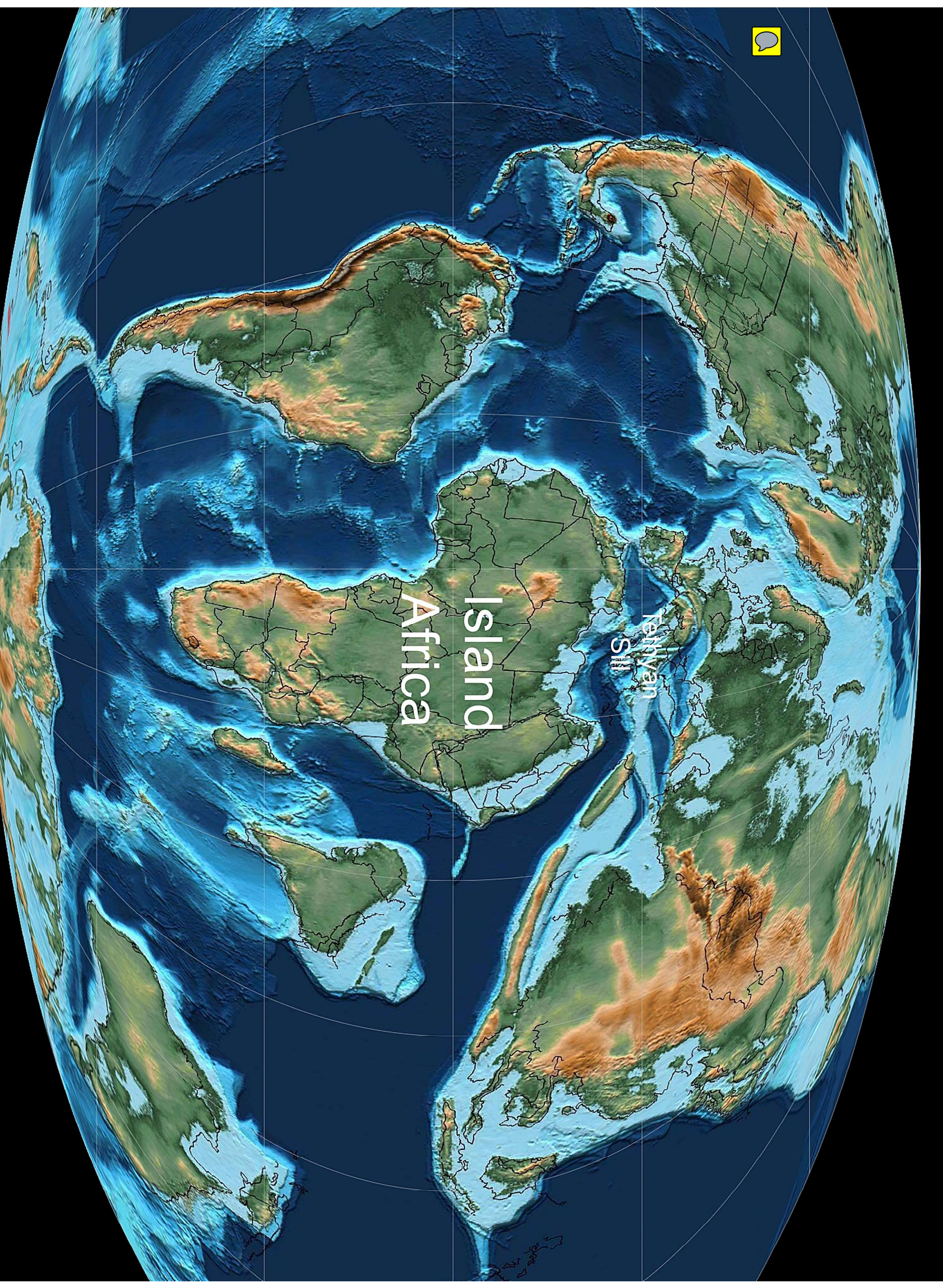




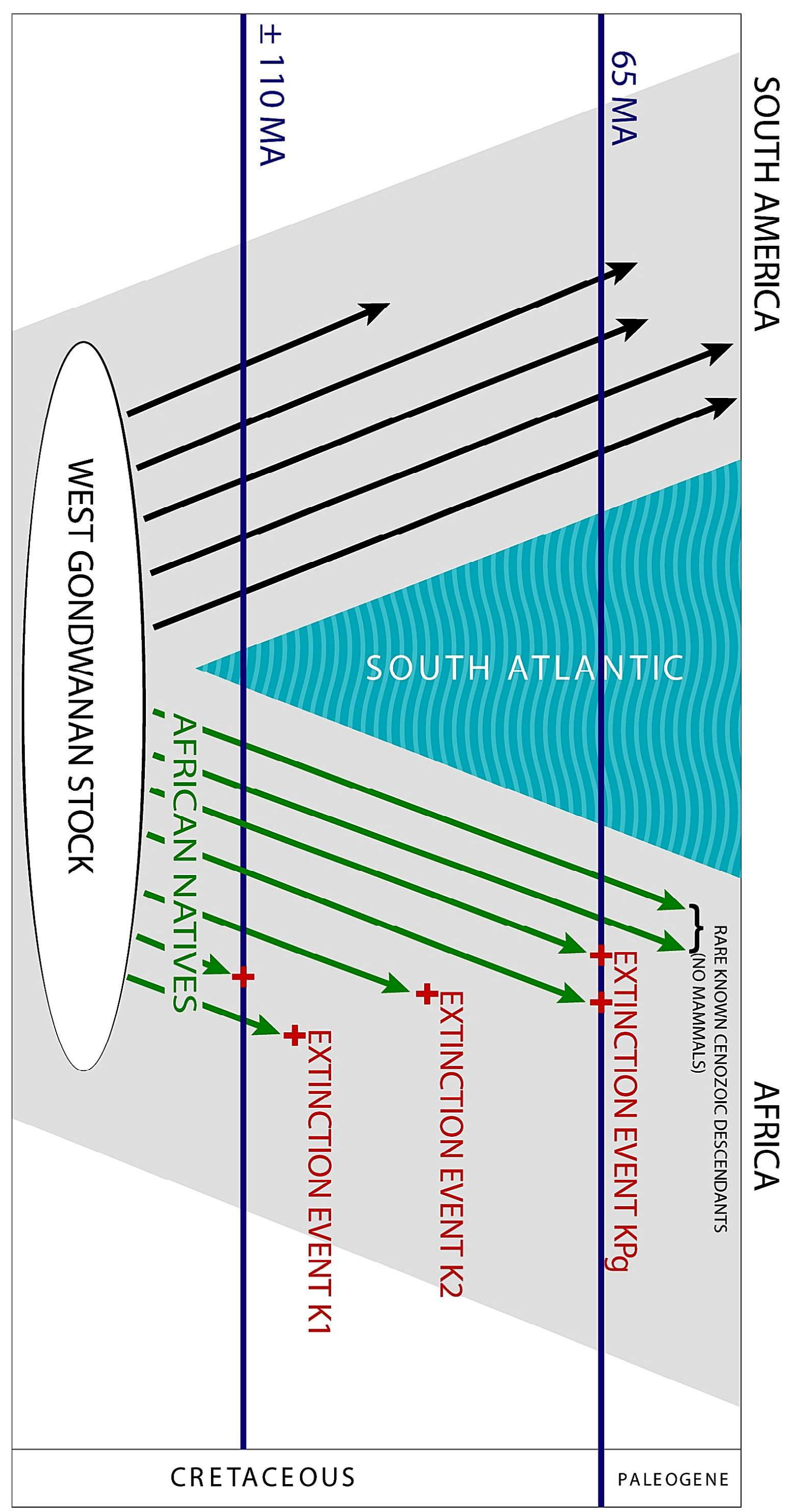

D 


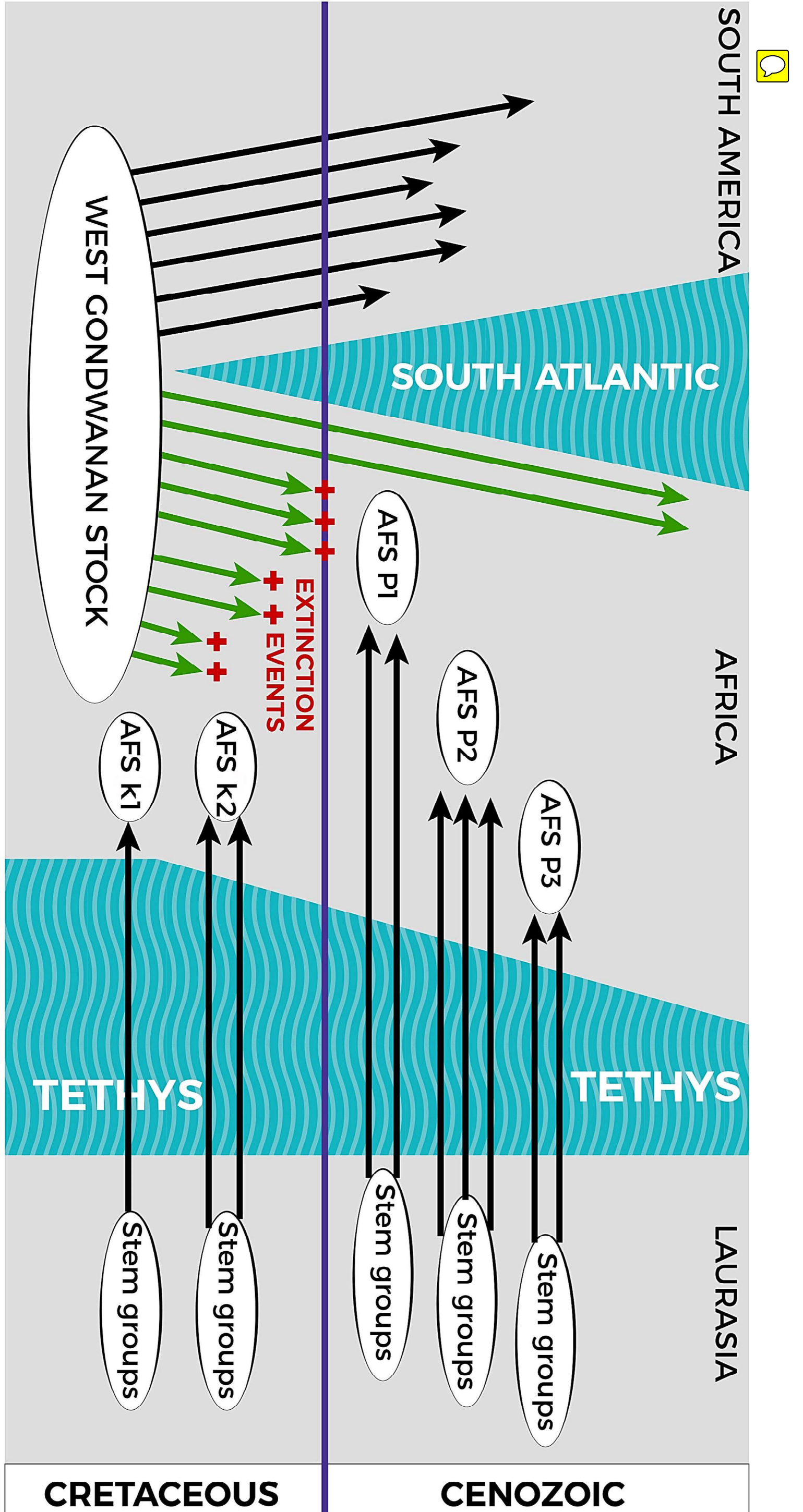

